\title{
THE IMPACT OF ENVIRONMENTAL CONDITIONS ON SHOPPING LOCATIONS: AN ANALYSIS OF THE AUSTRIAN MARIAHILFERSTRAßE
}

\author{
PETRA AMRUSCH \& FRANZ WIRL \\ University of Vienna, Austria
}

\begin{abstract}
This paper investigates the impact of a major revamping of a major in inner-city shopping location, more precisely, 'Mariahilferstraße' in Vienna. This street was also a major route to the (old) city centre. This route has been closed and the whole street is now (more or less) a pedestrian area. This unique event is used to fit hedonic pricing models in order to quantify in monetary terms the effects of less accessibility, traffic and pollution. Our findings are that property prices increase due to limiting urban motor traffic and promoting pedestrian areas in a major shopping street of Austria. Moreover, economic impacts of environmental measures are assessed, i.e. by deferring the willingness to pay for reduced urban traffic irrespective of accessibility.

Keywords: hedonic modelling, estimation of non-market value, Austrian housing market, valuation of traffic-related environmental conditions, willingness-to-pay for accessibility in shopping streets, neighbourhood effects, Mariahilferstraße.
\end{abstract}

\section{INTRODUCTION}

Contemporary hedonic research is characterized by an increasing interest in the interrelationship between urban design and the real estate development, as recognized by Nase et al. [1]. Several empirical studies evaluate the impact of pedestrian areas on housing, with results generally demonstrating significant relationships between prices and environmental conditions such as reduced traffic noise (as traced back by a literature survey by, i.e., Bartholomew and Ewing [2]). Recently, e.g., Fritsch et al. [3] make evident in a real estate study that "central pedestrian zone is equivalent to proximity to the main shopping facilities and tourist attractions where traffic noise is low" in an investigation area of Germany. A hedonic study on city tourism in Italy (Padua) shows comparable results [4].

Our study complements international hedonic findings on urban and environmental design of major shopping streets. We apply the hedonic model to the recent changes in urban and environmental design of the shopping street 'Mariahilferstraße' in Vienna (Austria), considering three street development stages (the pre-construction period of heavy traffic noise, the phase of construction and the post-construction period characterized by reduced traffic noise) in 2014-2015.

The decision of revamping of the shopping street was heavily disputed and corresponding surveys were conducted [5].

According to the research paper by Cushman and Wakefield [6], "a critical mass of shopping locations helps to create a destination that increases attractiveness to tourists and residents alike". Traffic limitation may contribute to environmental, social and economic benefits. In this paper, premiums attached to reduced motor traffic, reflected in residential real estate, in the vicinity of the Mariahilferstraße are estimated. The question posed is whether people are willing to pay for environmental and social benefits in exchange of limited private motor traffic in a shopping street with high passenger frequency irrespective of reduced accessibility by private transport. Are people willing to pay additional sums for the adjacency to an environmentally-friendly shopping street (i.e., with pavement cafes) 
accessible by public better than by private transport? Our goal is to monetarily determine the nonmarket value of proximity to a newly designed shopping street from the residential housing market under different urban transport conditions. More specifically, we investigate the value of proximity to an environmentally and passenger friendly shopping location under 'limited traffic' and 'unlimited traffic'.

Muehlenbachs et al. [7] describe adjacency effects as "all of the costs and benefits associated with close proximity" (to the respective nonmarket good or service).

In our study, costs involve restricted private transport accessibility and negative externalities of construction activities, whereas benefits include, i.e., less urban traffic pollution and improved public transport.

The use of hedonic regression analyses can be traced back to Rosen [8] and Freeman [9]. By applying hedonics, we estimate the premiums people attach to the Mariahilferstraße before and after the limitation of urban traffic, as well as in the transition period of construction works.

It is to be noted that real estate brokers suggest that the proximity to the Mariahilferstraße as a popular shopping and meeting point positively affects real estate prices (derived from real estate announcements published by brokers [10]).

In the next section, the investigated area is described, in the empirical part, the variables are described and a corresponding model is constructed, and finally, the willingness to pay for the proximity to the pedestrian area is determined.

\section{THE AUSTRIAN MARIAHILFERSTRAßE}

The shopping street, Mariahilferstraße, is considered to be the largest and one of the most popular shopping streets of Vienna and is internationally known as a main shopping street of the world by the real estate consultancy sector; Cushman and Wakefield predict the price level of rents in the Mariahilferstraße to be stable in 2016 [10]. The street is characterized by a notable percentage of passenger frequency in Vienna [11].

In 2014, the construction of the meeting and pedestrian area was budgeted at $€ 25$ billion over a period of 14 month (19.5.2014-31.7.2015) [12]. Moreover, measures have been taken to develop the public transport system, improving also the accessibility for people living in remoter areas of the 7 th district.

Geographically, the Mariahilferstraße is located between two districts (the 6th and 7th district). Because of the size differences in the districts (the surface of the 6th district - which is closer to the Mariahilferstraße - is marginally smaller than the 7th district); in the empirical part, dummy variables representing adjacency effects are differently set for 7th and 6th district.

\section{EMPIRICAL PART}

The hedonic technique is commonly applied in order to assess the willingness to pay for market and non-market characteristics capitalized in (real estate) market values, based on a couple of assumptions. In this paper, the hedonic pricing method is used to estimate the value of nonmarket goods, such as adjacency effects, capitalized in the residential housing price. Hereby, housing and location-specific characteristics as independent variables are regressed on the selling price of residential properties, in view of the theoretical assumptions underlying the hedonic model.

\subsection{Data}

The data on selling prices of residential real estate in the 6th and 7th district, denoted by $P$, along with housing characteristics, are provided by the Austrian journal Immo-Bazar [10] 
with a large range of real estate announcements in 2014 and 2015. The lowest apartment price in the sample is $€ 79,000$; the maximum price is $€ 1,656,000$, while the average price amounts to $€ 493,623$. It is to be noted that the average property size is 97 square meters.

In general, in hedonic modelling, perceived values (subjective values) should preferably be applied rather than measured (objective) values. Hence, all information about apartment characteristics (i.e. terrace, balcony, age) is gained from the Immo-Bazar [10] along with the price data.

\subsection{The hedonic regression and the definition of dummy variables}

In this paper, the residential property price, $P$, is defined as function of structural housing (such as apartment size in terms of square meters $(\mathrm{sqm})$ ), location-specific and/or neighbourhood characteristics (such as the adjacency to the Mariahilferstraße).

The construction works related to the creation of the new pedestrian area with limited motor traffic started in May 2014 and were finalized on the 1st of August 2015. Thus, a dummy variable for the construction period, denoted by $\mathbf{D}^{\mathbf{c}}$, is created, taking on the value one for the months of construction and zero otherwise. As a result, the complementary dummy (1- $\mathbf{D}^{\mathbf{c}}$ ) stands for the months with no construction works. The dummy variables $\mathbf{D}^{\mathbf{2 0 1 4}}$ and $\mathbf{D}^{\mathbf{2 0 1 5}}$ distinguish the year 2014 from the year 2015, with the value one for the years 2014 and 2015, respectively, and zero otherwise.

A further dummy variable $\left(\mathbf{D}^{\text {s.s }}\right)$ identifies the effect of perceived adjacency to the shopping street in the 7th district, taking on the value two, if the shopping street is considered to be very close to the apartment (i.e. if a very small distance or a distance of a few minutes to the shopping street is pointed out in the announcements). $\mathbf{D}^{\text {s.s }}$ is equal to one, if the distance to the shopping street is assumed to be of about 15 minutes by food (deduced from the address of the property and/or the vicinity of the shopping area mentioned in the announcements) in the 6 th and 7 th district and zero otherwise.

Proximity effects may interact with benefits of a scenic city view to the shopping street from a pent house. Thus, an additional dummy variable, denoted by $\mathbf{D}^{\mathbf{p}}$, is created, taking on the value one for pent houses and zero for the opposite case. Finally, a dummy variable, $\mathbf{D}^{\text {a.p }}$, characterizes the benefits of special luxury buildings, equalling one for apartments in historical palaces or buildings with a swimming pool and zero otherwise.

\subsection{Estimation of the willingness to pay for non-market and market characteristics}

Firstly, to avoid multicollinearity, highly correlated variables are eliminated, such as the number of rooms and the surface of the residential property in terms of square meters. The choice of functional form of the OLS-regression is primarily based on economic criteria, such as the expected relationship between the independent variables and the selling price of residential housing as well as on model selection criteria by testing frequently used functional forms.

The hedonic model is based on the assumption of homogeneity of preferences (e.g., Turner [13]). In order to consider habitable buildings, i.e. buildings with no major restructuring requirements and buildings not purchased for investment purposes only, all variables are multiplied by the dummy variable, $\mathbf{D}^{\mathbf{r}}$ (taking on the value one if the property is restored, and zero if the property is inhabitable). We formulated a model of the following form, eqn (1), using logarithmic transformations, where $P$ is a vector of housing purchase prices offered to the market; $\alpha, \beta, \gamma, \delta$ are the vectors of coefficients (of the transformed and no- transformed explanatory variables) to be estimated, $c$ characterizes the intercept and $\varepsilon$ is the error term: 


$$
\begin{gathered}
\ln (P) * D^{r}=c+\ln (s q m) * D^{r} * \alpha+D^{\text {s.s. }} *\left(1-D^{C}\right) * D^{2014} * D^{r} * \\
\left(1-D^{P}\right) * \beta+D^{\text {s.s. }} *\left(1-D^{C}\right) * D^{2015} * D^{r} *\left(1-D^{P}\right) * \gamma+ \\
D^{\text {a.p. }} * D^{r}+\delta * D^{2015} * D^{r} * \delta+\varepsilon
\end{gathered}
$$

By using a set of 299 observations $(N=299)$, a semi-log-specification is found to fit best the data set explaining about $94 \%$ of the variance of $\ln (\text { price })^{*} \mathrm{D}^{\mathrm{r}}$, whereby in addition to the dependent variable, only one independent variable, the surface of the property in term of square meters $(s q m)$, is transformed (Table 1). Due to the value of Jarque-Bera $(\mathrm{JB}=1.44)$ no deviation from normality of residuals is assumed in the regression.

By using White's heteroscedasticity-consistent estimates, in Table 1, all coefficients are highly significant (at a 0.99 confidence interval).

The hedonic regression (Table 1) shows that the adjacency of apartments (that are not pent houses) to the shopping street has a positive impact on residential housing prices in the period of no construction works (January-April/May 2014; August-December 2015), holding other coefficients constant. On the contrary, within the construction period, no significant property price effect of proximity to the shopping street is observed, presumably due to the interaction of negative effects of construction works (i.e., noise). For this reason, the independent variable representing adjacency effects during the construction period is excluded from the regression. This is surprising in the sense as the real estate market could not predict the positive effects that in the end resulted from this reconstruction.

More specifically, in the period of no construction works, we can say that on average a 15 -minute increase in proximity by food to the shopping street is associated with an increment in housing prices of about $46 \%$ and $56 \%$, in 2014 and 2015, respectively. In other words, if the apartment is around 15 minutes by food closer to the Mariahilferstraße, the price increase is about $€ 227,000$ before construction and $€ 276,400$ after construction activities, respectively. Thus, after the finalized construction works, the impact of adjacency to the Mariahilferstraße is even higher, suggesting that people are on average willing to pay more

\begin{tabular}{|c|c|}
\hline Constant and variables & Coefficients (with absolute t-statistics in parentheses) \\
\hline Constant & $\begin{array}{l}1.145523 \\
(4.2)\end{array}$ \\
\hline $\ln (s q m)^{*} \mathrm{D}^{\mathrm{r}}$ & $\begin{array}{l}2.547010 \\
(44.0)\end{array}$ \\
\hline $\begin{array}{l}\text { Adjacency to the street before } \\
\text { construction works } 2014 \text { (excl. pent }\end{array}$ & $\begin{array}{l}0.381684 \\
(2.8)\end{array}$ \\
\hline $\begin{array}{l}\text { Adjacency to the street after construction } \\
\text { works } 2015 \text { (excl. pent houses) } * D^{r}\end{array}$ & $\begin{array}{l}0.445234 \\
(9.6)\end{array}$ \\
\hline $\begin{array}{l}\text { Luxury properties with a pool and/or in } \\
\text { (historical) palaces* } \mathrm{D}^{\mathrm{r}}\end{array}$ & $\begin{array}{l}0.533801 \\
(6.2)\end{array}$ \\
\hline $\begin{array}{l}\text { time dummy variable ('after } 1.1 .2015 \text { ') * } \\
D^{r}\end{array}$ & $\begin{array}{l}0.550076 \\
(5.5)\end{array}$ \\
\hline
\end{tabular}
for living close to a more environmentally friendly Mariahilferstraße.

Table 1: Hedonic housing model for habitable (restored) residential real estate. 
Furthermore, as expected, results reveal a significant positive relationship between prices and apartments in historical palaces and/or luxury buildings with a pool. A 1 per cent increase in the apartment surface in terms of square meters implies an around 2-3 per cent increase in the property price, holding other characteristics constant.

\section{SUMMARY RESULTS AND FUTURE RESEARCH}

Our estimates suggest that people living in the bordering districts attach premiums to the adjacency to the Mariahilferstraße as one of the most important shopping streets of Austria, capitalized in the housing market. Interestingly, these premiums are even higher if motor traffic is limited and walkability is improved. Premiums increase despite reduced accessibility by private transport, presumably since negative effects are compensated by the improved public transport. However, there are no significant adjacency effects observed in the period of construction activities, possibly due to the interaction of negative externalities of construction works (involving i.e. noise, aesthetic factors, and reduced accessibility) with benefits of proximity.

The results display that people are on average willing to pay additional sums for the environmentally friendly street design. In order to evaluate whether the trend of increased positive adjacency effects of limited traffic will continue, future years may be studied. Since commercial activities also affect residential housing prices [14], another possible direction of future research could be the investigation whether possible changes in sales will affect the residential housing market in the long run, i.e. the next ten years (until 2026).

\section{REFERENCES}

[1] Nase, I., Berry, J. \& Adair, A., Hedonic modelling of high street retail properties: A quality design perspective. Journal of Property Investment \& Finance, 31(2), pp. 160-178, 2013.

[2] Bartholomew, K. \& Ewing, R., Hedonic price effects of pedestrian- and transitoriented development. Journal of Planning Literature, 26(1), pp. 18-34, 2011.

[3] Fritsch, M., Haupt, H. \& Ng, P.T., Urban house price surfaces near a World Heritage Site: Modeling conditional price and spatial heterogeneity. Regional Science and Urban Economics, 60, pp. 260-275, 2016.

[4] Amrusch, P., The relation between public services and the demand for sustainable city tourism. Sustainable Development and Planning III, WIT Transactions on Ecology and the Environment, pp. 1039-1048, 2007.

[5] wien.at: Magistrat der Stadt Wien. https://www.wien.gv.at/video/246379/Umfragezur-Neugestaltung-der-Mariahilfer-Strasse. Accessed on: 18 Jan. 2017.

[6] Cushman \& Wakefield, Main Streets across the World 2015-2016, Research Publication, 17th ed. http://www.cushmanwakefield.com/en/research-and-insight/ 2015/main-streets-across-the-world-2015/. Accessed on: 9 Dec. 2016.

[7] Muehlenbachs, L., Spiller, E. \& Timmins, C., The housing market impacts of shale gas development. American Economic Review, 105(12), pp. 3633-3659, 2015.

[8] Rosen, S., Hedonic prices and implicit markets: Product differentiation in pure competition. Journal of Political Economy, 82, pp. 34-55, 1974.

[9] Freeman, A.M., III., On estimating air pollution control benefits from land value studies. Journal of Environmental Economics and Management, 1(1), pp. 74-83, 1974.

[10] Immo-Bazar.at. Issues 2014-2015. www.bazar.at

[11] MA 18 - Stadtforschung und Raumanalysen, Gielge, J., Häberlin, U., Wirtschaftskammer Wien, Abteilung Stadtplanung und Verkehrspolitik, 2010. 
162 Ecosystems and Sustainable Development XI

https://www.wien.gv.at/stadtentwicklung/studien/pdf/b008164.pdf. Accessed on: 18 Jan. 2017.

[12] wien.at: Magistrat der Stadt Wien, Start zur Umgestaltung der Mariahilfer Straße. https://www.wien.gv.at/video/247795/Start-zur-Umgestaltung-der-Mariahilfer-

Strasse and https://www.wien.gv.at/verkehr/strassen/archiv/grossprojekte/mariahilfer strasse.html. Accessed on: 18 Jan. 2017.

[13] Turner, R.K., Sustainable Environmental Economics and Management: Principles and Practice, London, pp. 120, 226, 1993.

[14] Yu, T.H, Cho, S.H. \& Kim, S.G., Assessing the residential property tax revenue impact of a shopping center. Journal of Real Estate Finance and Economics, 45, 2012. 